\title{
Perceptions of Firms Learning and Growth under Knowledge Management Approach with Linkage to Balanced Scorecard (BSC): Evidence from a Multinational Corporation of Bangladesh
}

\author{
Md. Habib- Uz- Zaman Khan, ASA (Corresponding author) \\ Senior Lecturer \\ Department of Business Administration, Faculty of Business and Economics \\ East West University, Dhaka -1212, Bangladesh \\ Tel: 88-9887-989, Fax: 880-2-8812336 \\ E-mail: hzkhan@ewubd.edu,sumkadu@yahoo.com \\ Abdel Karim Halabi \\ School of Accountancy, University of the Witswaterrand \\ Private Bag 3, WITS, Gauteng, South Africa \\ E-mail: abdel.halabi@wits.ac.za
}

\begin{abstract}
The study attempts to measure organization's perception on learning and growth with the help of Balanced scorecard model in a multinational firm of Bangladesh. That is to say, in this paper it has been shown how a proper and effective knowledge management can make possible the organization's financial success that can be revealed using the Balanced Scorecard (BSC) framework. Additionally, the perception about knowledge management, its linkage to the BSC and its usage have been identified. Primary data collected for conducting this emperical research was carried out through survey method using structured questionnaire. Data were then analysed with the help of bi-variate and multi-vatiate techniques of statistics. Empirical results of our study suggest that learning and growing organization is one in which knowledge management activities are deployed and expanded with a view to leverage the creativity of all the people in the organization The result also evidenced that BSC, as a strategic performance measurement tool, helps in strategic management by linking some strategically significant, relevant, and interrelated measures or indicators with organizational emphasis on knowledge and learning initiatives .
\end{abstract}

Keywords: Knowledge management, Financial Perspective, Non-financial perspectives, Learning \& Growth, Bangladesh, MNC

\section{Introduction}

Knowledge has become the key economic resource and yet the only source of competitive advantage (Drucker, 1995). Nowadays, organizations compete in a complex and dynamic environment. That is why for achieving the organizational goals in the long run, a thorough understanding and monitoring of the overall business environment and appropriate implementation of the well-developed strategies through proper strategic management are essential. Strategic management process has been described as an objective, logical and systematic approach for making major decisions in all organization (David, 1999) which attempted to organize qualitative and quantitative information in a way that allows effective decisions to be made under the conditions of uncertainty. Stephens (2000) illustrated that a successful strategic management demands proper collection of information and knowledgeable utilization of information. According to management 'Guru' Peter Drucker (1995), "Knowledge is the only meaningful resource today". Berdow and Lane (2003) opined that now a days sharing and managing of knowledge have become a key issue of getting success for every organization in the highly competitive market. Human knowledge is considered as one of the most valuable intangible resources of an organization. It has been claimed that knowledge is the critical resource of the future. Knowledge is created through a blend of data and information by the human and this mixture is done through using 
people's own intuition (immediate insight) and experience in order that this knowledge adds value in taking actions. "It includes not only the 'old knowledge' that is in people's heads or the organization's databases but also the 'new knowledge' that is generated when people work with information from sources such as the Internet or when they work together with practitioners or communities of practice"(Stephens, 2000). When raw and unorganized data are organized and given a proper shape for using in a particular purpose, it becomes information. To become knowledge, all these data and information should be mixed with the intuition and experience of the human resource of the organization. Today's business environment is characterized by continuous, often radical changes climate. Such a volatile climate demands a new attitude and approach within organizations in where actions must be anticipatory, adaptive and based on a faster cycle of knowledge creation. Zander and Kogut (1992) measured 'organizational knowledge' that includes operational routines, skills, procedures and (know-how) as the most priceless asset of an organization. Knowledge management is a large issue that focuses on the full range of processes including the acquisition, retention, storage, distribution and use of knowledge in the organization. Management experts agree that learning and growth are the means of strategic victory, the basement for the future. Researchers ( e.g. Zander and Kogut 1992; Kaplan and Norton ,1996 ; Hoque et.al, 2000 ) echoed that learning and growing organization is one in which knowledge management activities are employed and expanded so as to support the workmanship of all the persons in the organization. In a knowledge-based organization, human beings are the only holding pool of knowledge. In the existing business atmosphere of expeditious technological evolution, it has been becoming substantive for knowledge workers to be a part of ceaseless learning domain. Kaplan and Norton (1996) highlighted on 'learning' more than just 'training' (Kabir, 2005). It also includes technological tools that help in learning and growth. Kaplan and Norton (1996) initiated the Balanced Scorecard (BSC hereafter) approach, a competent and conversant mechanism for successful strategic management. The BSC approach conceives learning and growth through 'knowledge' as the foundation for organizational success.

In Bangladesh Multinational Corporations (MNC) operates in a highly competitive environment due to the competition with other MNC and some local conglomerate(Ishtiaque et.al, 2007).This intense competitive and fast changing business environment increasingly demands more accurate and perfect information to measure business performance not only to get competitive advantage over others but only to survive. For the convenience of study a Multinational organization has been chosen who operates in Bangladesh for last several years. Moreover, the products and menufacturing process studied for this research is mobile phone sets. MNC's are a good source to provide enriched required information BSC implementation and it could be a solid platform to emperically test some undering theorical hypothesis (Hoque et.al, 2000). In this regard, MNC's perception regarding learning and growth under Knowledge management approach that would be linked with the Balanced Scorecard model in the firm's operation has been analyzed. BSC which is a measurement, strategic management and communication tool that enables organizations to translate a company's vision and strategy into implementation, may provide more accurate and relevant information to MNC's by linking their strategies with their action.

The main objectives of this article are to connect Learning and Growth under Knowledge Management approach with BSC in Multinational organizations, and to establish the fact that the success of knowledge management can be measured by Balanced Scorecard. Besides, the paper aims to achieve following specifics objectives (a) To identify the extent of use of BSc in the Multinational organizations operating in Bangladesh. (b) To provide a general view of employees about the importance of employee learning and growth. (c) To identify the key ways to increase organization's learning ability. (d) To recommend on proper use of employees learning and in excelling their job knowledge

Therefore, this paper is effectively developed through the given sequence: Following the introduction, it has focused on the review of literature and development of the hypotheses have been depicted to make it more reliable and valid.This is followed by the research method applied for the study. Next, emperical findings is provided for the result of the hypotheses. The last section highlights recommendations along with conclusions and limitations of the study.

\section{Literature review and hypotheses development}

Knowledge management implies a range of practices used by organisations to identify, create, represent and distribute knowledge for reuse, awareness and learning across the organisations. This programs attempt to manage the process of creation or identification, accumulation, and application of knowledge across an organisation (Davenport and Prusak, 1997). Knowledge management has been defined by many authors from different perspectives. Some of them thought it commercially while few others in another form" ... knowledge is all about the need to know to be competitive (e.g. Time to Market). This need to know is ultimately necessary for our survival, and in particular, to enhance our decision-making processes, although our successes will ultimately depend on worthy, on-time and on-line know how - knowledge" (Davis, 2002). In order to know something, a human being has a number of resources available in his/her environment. These resources can be data, information, expertise, intuition, life experiences, opinion from different people, several published documents, etc. In business, knowledge is all about the need to know to become competitive in the market. This need to know ultimately helps in surviving in the long run and it also enhances the 
decision-making processes. Myers (1996) addressed Knowledge management as "... we call identify and then manage- organizational knowledge only to the extent it has been captured by all organization systems, processes, products, rules, and culture" (p.23). The victory of a business depends on meritorious, on time deployment of knowledge. Knowledge arising from intuition and experience is indispensable in making good strategic decision, which is particularly practical for making decisions where there is an immense uncertainty. This should be complemented with strategic management analyses. Most organizations benefit from strategic management that is based upon knowledge creation and analysis in decision-making. Business organizations can get competitive advantage in hyper competitive markets by developing organizational knowledge through strategic planning (Akhter, 2003). In the research report published by KPMG (2000), knowledge is mentioned as "about customers, products, processes, competitors etc" that can be codified in people's mind or in an explicit form. Prior research studies ( e.g. BML Consulting, 2002; Berdow and Lane, 2003 ) pointed knowledge management out as 'A company's knowledge must include technical knowledge as well as knowledge about how to function in the global market, work with local laws, how to protect intellectual property, and how to operate successfully in various forms of partnerships. Businesses can only survive and thrive by exploiting every possible advantage in the increasingly competitive market. Therefore, now a day, it is well accepted all over the globe that a sustainable competitive advantage and profitability depends highly on how a company creates and shares its knowledge (Desouza, 2003). This competitive environment begets the theme of knowledge management in the mind of management thinkers.

Stephen (2000) opined this as "Knowledge management is getting the right knowledge to the right people at the right time to serve the right objectives. It is a management philosophy that combines purposeful information management with a culture of organizational learning in order to improve the business performance. It should be the task of the organizational leaders to create an environment in the organization for managing the knowledge. Knowledge management involves connecting people through developing a culture of sharing knowledge and discouraging 'hoarding' of knowledge." To serve the market in an efficient way it is crucial that the human resource of an organization should be well updated about the market and their responsibilities. Today's organizational employees and decision-makers need to be information knowledgeable (Drucker, 1992). The use of Information Technology (IT) has led to a new era of sharing information and knowledge to them. The information system can create smart human who has the capability to anticipate the market (Stephens, 2000). The employees should always focus on the activities of their competitors and the demand and behavior of their customers. For this, they need information in advance for which information technologies have improved the ability to manage both information and knowledge from the aspects of collection, storage, and circulation. The success of knowledge management activities rely on people who appropriately use the knowledge exchange and utilization process. Through this, people can have better idea about their organization and know how several options can well be utilized. However, a few things are to be rememberd here that knowledge management does not have a beginning and an end, it is ongoing, organic and ever-evolving.

\section{Organizational learning and Knowledge Management}

Organizational learning has become an increasingly important concept in today's business world. Awad et al (2004) defined it as:" The development of insights, knowledge and associations between past actions, the effectiveness of those actions, and future action" (p.8).Therefore it is argued that learning and knowledge management are two key aspects of judging a successful company.

In a 'knowledge company', knowledge is more easily transferred and made accessible to workers throughout the organization. When people have access to organizational knowledge, they can understand their environment and give it meaning. This can assist them performing better through continuous learning, share a vision and ultimately help the organization to become competitive. The financial, customer and internal perspectives generally lead to knowledge of weaknesses in an organization's infrastructure, skills, automation which are restricting the organization to achieve better results. Focusing on these helps development of suitable measures to ensure that organization channels it's investments properly to address all needs not only for infrastructure, but also on research and development, human capital development, improving employee satisfaction and increasing employee motivation. Organizational learning ability can be increased by a number of ways. Rampersad (2002) pointed these out as (1) Creating conditions whereby people are willing to apply their knowledge, share and intensively exchange it with each other (2) establishing the organizational structure in such a way that people get sufficient space and opportunities to gain experiences and thinking (3) Stimulating employees to formulate their own personal Balanced Scorecard and through this cultivate a positive attitude toward improvement, learning and development(4) Making an inventory of the learning style and aligning it to the personal ambition, reviewing this periodically; aligning it to the planning, coaching and appraisal meetings and the $360^{\circ}$-feedback system (5) Establishing improvement teams in which a balance of personalities, skills and learning styles is present (6) Developing and accepting self knowledge regarding their own favourite learning style and the ones of other team members, Giving people a sense of direction based on a shared ambition and linking them to each other (7) Working with teams where team learning is central; teams that think and act from a synergetic perspective, and are well coordinated, with a feeling of unity (8) Using images, metaphors and intuitions to share and exchange implicit 
knowledge and working with self-directing teams in an organizational network, using generalists with ample responsibilities and competences and where there are knowledge overlaps and task rotations between employees (9) Stimulating employees to think about, identify and solve common problems as a team, letting traditional ways of thinking, constantly develop their own skills, allowing them to acquire experience and allow them feel responsible for company and team performances (10) Having leaders who coach, help, inspire, motivate and stimulate, are action oriented, and constantly evaluate processes based on performance measures (11) Having people who continually learn from their mistakes and openly communicate with each other, and constantly apply Deming's and Kolb's learning cycles in their actions Systematically working with problem solving methods (brainstorming, problem solving cycle, risk management etc (12) Giving feedback about improvement actions undertaken. and (12) Implementing a knowledge infrastructure; internet, intranet, library, evaluation sessions where allowing employees to concentrate on everything that happens in the organization.

\section{The Balanced Scorecard (BSC) approach and its application:}

The Balanced Scorecard (BSC) is a measurement, strategic management and communication tool (Kaplan and Norton, 1996). It is a measurement tool because it helps organizations to identify quantifiable measures of performance. In the recent past organizations rely solely on financial indicators as the measures of their business performance. This has proved grossly inadequate essentially because financial indicators are only a reflection of the past performance with little or no relevance to the future. The BSC balances the financial indicators with non- financial indicators of performance. It is also viewed as a strategic management tools because it helps organizations to make parallel of individual objectives with the corporate objectives. BSC is also called the communication tool because it communicates an otherwise unknown strategy of the organization to the employees. (Ogundipe, 2003). BSC introduced by Kaplan and Norton (1992) is a concept for measuring a company's activities in terms of its vision and strategies, for letting managers a comprehensive view of the performance of a business. Managers, using this BSC approach, do not have to rely on short-term financial measures as the sole indicators of organization's performance (Kaplan and Norton, 1996). The BSC approach allows managers to look at the business from four different perspectives. It provides answer to four basic questions which are shown in the following diagram.

Insert Figure 1 here

As the name suggests, "Balanced" calls for a balance between financial and non-financial measure, long term and short-term objectives and external and internal performance. Scorecard' initially came into being as a measurement system, and gradually evolved into a core management system. Balanced Scorecard continues to emphasize on the financial performance measure but at the same time highlights future performance drivers, key initiatives to be taken and provides a framework for strategic management. It has been designed around four perspectives - financial, customer, internal business process and learning and growth.

Balanced Scorecard articulates customer and market-based strategy that will deliver super value to customer, build customer loyalty and bring superior financial results. It specifically looks at the value proposition that the organization will deliver to the customer in target market segment. It identifies critical new internal processes in which the organization must excel for future financial performance. In BSC, financial perspective is always important. Hoque et.al (1997) mentioned that healthy revenue growth, proper utilization of assets and investment strategy are also necessary for any organization. Here, key indicators are operating income, Return on Investment (ROI), Net Profit (NP), Earnings per Share (EPS), Sales growth, Generation of cash flows and Economic Value Added (EVA) (Evans, 2004; Banker et al, 2004; Lipe \& Salterio 2000 ; 2002)

In Internal Business Process perspective key indicators are product design, product development, manufacturing efficiency and quality. This perspective allows the managers to know how well their business is running, and and whether its products and services conform to their mission. Customer satisfaction perspective includes customer satisfaction survey (Kaplan and Norton, 1996a; Evans , 2004) customer retention (Hoque et.al, 1997) new customer acquisition, customer response time, market share(Evans, 2004; Banker et al . 2004; Zimmerman, 2003; Malina and Selto, 2001; Kaplan \& Atkinson, 1998; Kaplan \& Norton, 1996a) , post-sales service (Evans, 2004; Kaplan \& Norton, 1996a; Hoque , 2003) and customer profitability. Learning and growth perspective includes employee training and corporate cultural attitudes related to both individual and corporate self-improvement, Investments in new Technology (Zimmerman, 2001; Kaplan \& Norton,1996a);Innovative Products \& Services (Evans, 2004; Kaplan \& Norton1996a). It also includes information such as intellectual abilities of employees, information systems, and organizational procedures to manage a business and adaptation ability to changes, employee's training and development and employee satisfaction. (Kaplan \& Norton, 1996a; Istiaque et al ,2007; M. Lebas, 1995). It is noteworthy to mention here that Kaplan and Norton do not disregard the traditional need for financial data. Timely and accurate financial data is always relevant, important and managers should always provide it. However, it is important to state that the emphasis on only financial performance measurement tools leads to an unbalanced decision. This is because it shows fairly a disregard to other important perspectives. Recent management philosophy emphasizes on the importance of customer 
focus and customer satisfaction in any kind of business. There is no doubt that if customers are not satisfied, they will eventually find some other suppliers who will meet their needs. In such case,even if current financial performance shows a good picture, an unsatisfactory performance from customer perspective may result in a future deterioration. That is why organization put greater emphasis to address of all the perspectives of BSC that are strategically linked with the overall mission and vision of the organization.

The basis premise of BSC is that learning is necessary to improve internal business process, improving business process is necessary to improve customer satisfaction and improving customer satisfaction is necessary to improve the financial results. (Garrison and Noreen, 2000). Basically it indicates some cause- and - effect relationship among the perspectives (Aidemark, 2001). Kaplan and Norton (1992) stated these relationships showed in the following Figure.

Insert Figure 2 here

A research survey show that $60 \%$ of the Fortune 1000 firms have experimented with the BSC approach (Sild, 1998). But Hoque et. al. (1997) stated that little evidence is available outside the US on current practice of BSc practice in multinational organizations. Adopters include organizations like KPMG Peat Marwick, Allstate Insurance, AT \& T etc. (Chow et. al, 1997). However, many other researches suggest that there has also been increased evidences of using Balanced Scorecards outside the USA. A semi-structured interviews conducted by Malmi (2001) in 17 organizations in Finland found the widespread application of BSC approach. Kald and Nilsson (2000) in their research study on oil Nordic countries (Danish, Finish, Norway, Swedish) found that a majority of the companies of these countries have adopted BSC. According to Atkinson et al (1997), BSC has the potential to provide planners with a way of expressing and testing a sophisticated model of cause and effect in the organization, a model- that provides managers with a keystone to manage desired and actual results. Otley (1994) states that "it seems clear that the BSC approach has something to offer, but also that the study of management control is more complicated and more contingent than previously recognized". The BSC is among the most significant developments in the management accounting and thus deserves intense research attention (Atkinson et. al, 1997).

\section{Hypotheses Development}

From the abovementioned extensive discussion of past literature, the following hypotheses have been formulated to develop the empirical model of the study. It is noteworthy that all these perspectives are interrelated and affect significantly the financial performance of an organization.

Learning and Growth Perspective, Internal Business Process Perspective,

Customer Satisfaction. Financial Perspective. 


\begin{tabular}{|c|c|c|}
\hline$H_{o}: \mu_{X_{t}}=3$ & $H_{0}: \mu_{n}-3$ & $H_{0}: \mu_{X i s}=3$ \\
\hline$H_{j} \mu_{X_{l}} \neq 3$ & $\begin{array}{l}H_{j}: \mu_{X_{i 0}}=3 \\
H_{0}: \mu_{,}-3\end{array}$ & $\begin{array}{l}H_{o}: \mu_{X I S}=3 \\
H_{0}: \mu_{X=3}=3\end{array}$ \\
\hline $\begin{array}{l}H_{0}: \mu_{X}=3 \\
H_{i}: \mu_{X_{z}} \neq 3\end{array}$ & $H_{j}: \mu_{X_{u}}=3$ & $\begin{array}{l}H_{i} \mu_{X, 9} \neq 3 \\
H_{O}: \mu_{X_{20}} 3\end{array}$ \\
\hline$H_{O}: \mu_{X}=3$ & $H_{0}: \mu_{12}-3$ & $H_{o}: \mu_{X 20} \neq 3$ \\
\hline$H_{i}: \mu_{X_{3}}=3$ & $H_{k}: \mu_{X_{i 2}}=3$ & $H_{o}: \mu_{X_{2 I}}=3$ \\
\hline$H_{0}: \mu_{X_{4}}=3$ & $H_{0}: \mu_{13}=3$ & $H_{0}: \mu_{X 21} \neq 3$ \\
\hline$H_{f}: \mu_{X}=3$ & $H_{i} \mu_{X_{i 3}}=3$ & $H_{0}: \mu_{X 22}=3$ \\
\hline$H_{O}: \mu_{X \mathrm{t}}=3$ & $H_{0}: \mu_{14}=3$ & $H_{0}: \mu_{X 22}=3$ \\
\hline$H_{j}: \mu_{X_{5}}=3$ & $H_{i} \mu_{X_{i 4}}^{\#} 3$ & $H_{0}: \mu_{X_{23}} 3$ \\
\hline$H_{0}: \mu_{\ldots}-3$ & $H_{0}: \mu_{15}=3$ & $H_{O}: \mu_{X 23} \neq 3$ \\
\hline$H_{z}: \mu_{X_{6}}=3$ & $H_{i} \mu_{X_{3}}=3$ & $H_{0}: \mu_{X_{z \Delta}} 3$ \\
\hline$H_{0}: \mu_{7}=3$ & $H_{o}: \mu_{16}=3$ & $H_{0}: \mu_{X 24}=3$ \\
\hline $\begin{array}{l}H_{f}: \mu_{X 7}=3 \\
H_{0}: \mu_{8}-3\end{array}$ & $\begin{array}{l}H_{i} \mu_{X_{76}}=3 \\
H_{0}: \mu_{n}=3\end{array}$ & $H_{0}: \mu_{X 25}=3$ \\
\hline $\begin{array}{l}H_{f}: \mu_{X_{s}}=3 \\
H_{0}: \mu_{9}-3\end{array}$ & $H_{i} \mu_{X_{i}}=3$ & $\begin{array}{l}H_{0}: \mu_{X>3}=3 \\
H_{0}: \mu_{X 26} \neq 3\end{array}$ \\
\hline$H_{f}: \mu_{X_{9}}=3$ & & \\
\hline
\end{tabular}


Where, $\mu=$ Mean score;

$\boldsymbol{X}_{\boldsymbol{I}}=$ Employee suggestions are encouraged by the management.

$\mathbf{X}_{\mathbf{2}}=$ Organization conducts frequent trainings and development program for employees.

$\mathbf{X}_{\mathbf{3}}=$ Employee turnover is low.

$\mathbf{X}_{\mathbf{4}}=$ Number of hours spent for training per employee is high.

$\mathbf{X}_{\mathbf{5}}=$ Job security is ensured.

$\mathrm{X}_{\mathbf{6}}=$ Knowledge and learning competences are part of every employee's competence profile.

$\mathbf{X}_{7}=$ Organizational knowledge is shared through informal contacts, internal lectures, conferences, problem solving and project review meetings, dialogue sessions, memos, etc

$\mathbf{X}_{\mathbf{8}}=$ Knowledge sharing is facilitated through internet, intranet, library, comfortable meeting rooms, auditorium, computerized archive and documentation system, etc.

$\mathbf{X}_{\mathbf{9}}=$ Making mistakes is allowed; failures are tolerated and not penalized. People learn from each other's mistakes, and errors are openly discussed.

$\mathbf{X}_{\mathbf{1 0}}=$ The necessary knowledge for important decisions is usually readily available and easily accessible.

$\mathbf{X}_{11}=$ There is a continuous collective learning effort to develop the core competences of the organization.

$\mathbf{X}_{\mathbf{1 2}}=$ Users friendly communication and information systems are used to spread the knowledge among all the employees.

$\mathbf{X}_{13}=$ Management Information systems (MIS) are integrated and continually updated.

$\mathbf{X}_{14}=$ Gathered Knowledge is constantly being implemented and incorporated into new products, services and processes.

$\mathbf{X}_{15}=$ There is an active program for developing ideas. Based on this, new knowledge is continually generated and used in the improvement of business process

$\mathbf{X}_{\mathbf{1 6}}=$ On time(Proper) deliveries are high in all deliveries

$\mathbf{X}_{\mathbf{1 7}}=$ Percentages of defect free units are high of completed units.

$\mathbf{X}_{\mathbf{1 8}}=$ Improved business process acquiring from learning lead to improved products and service to the customer and their satisfaction.

$\mathbf{X}_{\mathbf{1 9}=}$ Customer satisfaction is measured by survey results.

$\mathbf{X}_{\mathbf{2 0}}=$ Product return policy is satisfactory to customers.

$\mathbf{X}_{\mathbf{2 1}}=$ Percentage of customer retention has risen from last period.

$\mathbf{X}_{\mathbf{2 2}}=$ Number of new customers has increased from last period.

$\mathbf{X}_{\mathbf{2 3}}=$ satisfied and loyal customer leads to increased revenues

$\boldsymbol{X}_{24}=$ Gross margin percentage has increased from the last period

$\boldsymbol{X}_{25}==$ Net profit percentage has increased from the last period

$\boldsymbol{X}_{26}=$ ROA percentage has increased from the last period.

\section{Insert Figure 3 here}

\section{Research Method}

The nature of the research process is quantitative research. Both primary and secondary data have been collected for this study. Primary data have been collected through personal interview from respondents using the structured questionnaire. On the other hand, secondary data were accumulated from different published text books, related journals, reports, and research works.Structured questionnaire was used in tapping the information which was designed in the light of the objectives of the study according to the pattern of the Balanced Scorecard model (Garrison and Noreen, 2000). In this study, interval scale was used to detect all the factors which touch all the four dimensions of Balanced Scorecard model and the technique was five point Likert scale anchored at the numeral 1 with the verbal statement 'strongly disagree' and at the numeral 5 with the verbal statement 'strongly agree'. The questionnaire was pre-tested several times to ensure 
that the wording, format, length, and sequencing of questions were appropriate.

In designing the sampling process, the target population includes those sampling elements that are involved with the target company (MNC) and are associated with at least five years. Due to the privacy policy of the study, the name of the company has not been disclosed. As a technique, stratified random sampling (Zikmund, 2003) was applied (as the samples are internally homogeneous and externally heterogeneous) with a view to increase precision by dividing population into strata i.e. customers and employees of the organization. Then sampling elements are selected from each stratum by applying Simple Random Sampling (SRS) procedure. In this case, sample units were 2 and sample size was 60 both for the employees and the customers. Surveys are burdened with problems linked to measurement error and bias, problems that may be aggravated when the survey is written in the respondents' second official language. (The concern of language is, conceivably, less important in the Bangladeshi perspective where fluency in English is very common, especially among top managers due to their high academic background and professional attainment).In the study, the Cronbach's Alpha test had been used in order to assess whether the variables accumulated to calculate the four factors were reliably measured. The results of this test $(\alpha=0.6104)$ as shown in Table 1 , indicates that all variables are effectively measured since all four factors' Cronbach's Alpha reliability values are above 0.60 (Nunally, 1978 and Bagozzi, 1994).

Malhotra (2004) states Cronbach's Alpha as:

...is the average of all possible split-half coefficients resulting from different ways of splitting the scale items. The coefficients vary from 0 to 1 and a value of 0.60 or more indicates satisfactory reliability.

To conduct data analysis, at first, all hypotheses under each four perspectives have been tested for their significance by paired comparison $t$ test through SPSS program and then finally the acceptance of a hypothesis has served the basis for further analysis. The data analysis part of the research includes identification of several variables in each four perspectives: Learning and growth perspective (13), Internal business process perspective (4), Customer perspective (5) and Financial perspective (4), then through factor analysis the variables have been rotated and the major variables have been discovered through which significant portion of the changes in each of the perspectives outcome were explained.

\section{Discussion of Empirical results}

\section{Emperical Results of hypotheses testing (One sample T test)}

\section{Learning and growth (Knowledge Management) perspective:}

The result of above hypotheses reveal that hypothesis denoted through $\mathrm{X}_{3}, \mathrm{X}_{4}, \mathrm{X}_{6}, \mathrm{X}_{7}, \mathrm{X}_{8}, \mathrm{X}_{10}$ are significant and therefore accepted as their derived probability is less than 0.05 (See appendix). However, $X_{1}, X_{2}, X_{5}, X_{9}, X_{11}, X_{12}, X_{13}$, are not accepted as the derived values of these hypotheses $(0.081,0.135,0.646,0.684,0.066,0.546$ and 0.155$)$ are greater than 0.05 . Thus findings reflect that employees turnover is low; Number of hours is spent for training per employee is high; Knowledge and learning competences are part of every employee's competence profile, Organizational knowledge is shared through informal contacts, internal lectures, conferences, problem solving and project review meetings, dialogue sessions, memos, etc; The necessary knowledge for important decisions is usually readily available and easily accessible. However, it is also reflected that employee suggestions are not considered by the top management; The organization does not conduct frequent training and development program for employees; Job security is not ensured; Making mistakes are not allowed; failures are not tolerated and penalized. People learn from each other's mistakes, and errors are not openly discussed; Continuous collective learning effort to develop the core competences of the organization is not available; Users friendly communication and information systems are not used to spread knowledge among all employees And Management information systems (MIS) are not integrated and continually updated.

\section{Internal Business Process perspective:}

The result of above hypotheses reveal that hypothesis denoted through $\mathrm{X}_{14}, \mathrm{X}_{16}, \mathrm{X}_{17}$, are significant and therefore accepted as their derived probability is less than 0.05 (See appendix). However, $\mathrm{X}_{15}$ are not accepted as the derived values of the hypotheses $(0.255)$ is greater than 0.05 . Thus findings reflect that gathered knowledge is constantly being implemented and incorporated into new products, services and processes; on time (Proper) deliveries are high in all deliveries; Percentages of defect free units are high of completed units. But in the organization, there is no active program for developing ideas and based on this, new knowledge is continually generated and used in the improvement of business process.

\section{Customer Satisfaction perspective :}

The result of above hypotheses reveal that hypothesis denoted through $\mathrm{X}_{18}, \mathrm{X}_{20}, \mathrm{X}_{21}, \mathrm{X}_{22}$, are significant and therefore accepted as their derived probability is less than 0.05 (See appendix). However, $X_{19}$ are not accepted as the derived values of the hypotheses (0.077) is greater than 0.05 . Thus findings reflect that Improved business process acquiring from learning lead to improved products and service to the customer and their satisfaction; Product return policy is 
satisfactory to customers; Percentage of customer retention has risen from last period; Number of new customers has increased from last period.However, in this organization, Customer satisfaction is not measured by survey results.

\section{Financial perspective:}

The result of above hypotheses reveal that hypothesis denoted through $\mathrm{X}_{23}, \mathrm{X}_{24}, \mathrm{X}_{25}, \mathrm{X}_{26}$, are significant and therefore accepted as their derived probability is less than 0.05 (See appendix). Thus findings reflect that satisfied and loyal customers lead to increased revenues; Gross margin percentage has increased from the last period; Net Income percentage has increased from the last period; ROA percentage has increased from the last period.

\section{Results of factor analysis}

Factor analysis was performed with the primary goal of data reduction and data summerization.The principal components method, using varimax rotation, reduced the 26 explanatory variables to 4 factors. [Malhotra, 2004]. For the sake of convergent validity, 0.4 was used as a factor loading cut-off point. Factors including less than two items were eliminated. [Jabnoun, 2003]. A principal components analysis (PCA) with varimax rotation was performed for four broad measures to determine their groups. However, prior to performing PCA, the suitability of data for factor analysis was assessed dully. An inspection of the correlation matrix revealed the presence of many coefficients of 0.30 and above, signifying that factor analysis is considered appropriate (Pallant, 2001). The Bartlett Test of Sphericity and Kaiser-Meyer-Olkin (KMO) were also used to assess the factorability of the data. The results indicate that the Bartlett Test of Sphericity (Bartlett, 1954) reached statistical significance (Chi-Square $=929.65, \mathrm{p}<.01$ ) and the KaiserMeyer-Olkin (KMO) Measure of Sampling Adequacy was 0.76, exceeding the recommended value of 0.60 (Kaiser, 1974). These results suggest that the factorability of the data is considered appropriate.

Interpretation of the factor loading matrix was straightforward. The factors are extracted in such a way that the first factor accounts for the highest variance in the data, the second the next highest and so on. Each table lists the factors in the order in which they were extracted. Therefore, Factor analysis has guided us to identify the variables which have high degree of involvement to the Balanced Scorecard as well as the variables which are comparatively less prominent in this regard [Malhotra, 2004].

\section{Learning and growth (Knowledge Management) perspective}

From factor analysis under varimax rotation, five factors have been extracted under learning and growth perspective. 
[Table 3]

\begin{tabular}{|c|c|c|c|}
\hline Factor & $\begin{array}{l}\text { Factor Interpretation (\% } \\
\text { variance explained }\end{array}$ & Loading & Variables included in the factor \\
\hline \multirow[t]{4}{*}{$F_{1}$} & \multirow{4}{*}{$\begin{array}{c}\text { Training and job security } \\
(17.237 \%)\end{array}$} & 0.842 & Mistakes, failures are allowed \\
\hline & & 0.609 & Knowledge is shared through various forms \\
\hline & & $0 \quad-.694$ & Users' friendly Communication system. \\
\hline & & $0-629$ & Management Information Systems ( MIS) \\
\hline \multirow[t]{3}{*}{$F_{2}$} & \multirow[t]{3}{*}{$\begin{array}{c}\text { Train ing hour } \\
(16.146 \%)\end{array}$} & $\begin{array}{ll}0 & .941\end{array}$ & Training hour per employees \\
\hline & & 0.868 & $\begin{array}{cc}\text { Knowledge } & \begin{array}{c}\text { sharing is facilited through various } \\
\text { forms. }\end{array}\end{array}$ \\
\hline & & 0.570 & Frequency of training and development programs. \\
\hline \multirow[t]{2}{*}{$F_{3}$} & \multirow{2}{*}{$\begin{array}{l}\text { Forms of knowledge } \\
\text { shared } \\
(15.776 \%)\end{array}$} & $0 \quad .903$ & Employees turnover \\
\hline & & 0.896 & $\begin{array}{c}\text { Knowledge sharing is facilited through various } \\
\text { forms }\end{array}$ \\
\hline \multirow[t]{2}{*}{$F_{4}$} & \multirow{2}{*}{$\begin{array}{c}\text { Core competance } \\
(15.776 \%)\end{array}$} & $0 \quad .903$ & Knowledge and learning as a core competance \\
\hline & & 0.848 & Suggestion from employees' \\
\hline \multirow[t]{2}{*}{$F_{5}$} & \multirow[t]{2}{*}{$\begin{array}{r}\text { Job secuirity } \\
(15.776 \%)\end{array}$} & $\begin{array}{ll}0 & .758\end{array}$ & Job secuirity. \\
\hline & & 0.744 & learning efforts for core competence \\
\hline
\end{tabular}

In all, the five factors explained 83.386 percent of the total variance of the learning and growth (Knowledge Management) perspective. The factor "Information readily avaiable" was eliminated (.926) because it included only one items with factor loading of 0.4 or above (Nunally, 1978)

\section{Internal busniness Process perspective}

From factor analysis under varimax rotation, two factors have been extracted under internal business process perspective. [Table 6 and Table 7] 


\begin{tabular}{|c|c|c|c|}
\hline Factor & $\begin{array}{c}\text { Factor Interpretation } \\
\text { (\% variance } \\
\text { explained }\end{array}$ & Loading & $\begin{array}{c}\text { Variables included in the } \\
\text { factor }\end{array}$ \\
\hline$F_{1}$ & $\begin{array}{c}\text { New ideas for } \\
\text { product }\end{array}$ & 0.834 & $\begin{array}{c}\text { Implementation of } \\
\text { gathered knowledge }\end{array}$ \\
\cline { 3 - 4 } & $(36.886 \%)$ & 0.784 & $\begin{array}{c}\text { Active programe for } \\
\text { generating new ideas }\end{array}$ \\
\hline $\boldsymbol{F}_{2}$ & $\begin{array}{c}\text { Zero- defects } \\
\text { policies } \\
(27.777 \%)\end{array}$ & 0.820 & $\begin{array}{c}\text { Percentage of defects } \\
\text { free units }\end{array}$ \\
\cline { 3 - 4 } & & 0.620 & $\begin{array}{c}\text { On time delivery } \\
\end{array}$ \\
& & & \\
\hline
\end{tabular}

In all, the two factors explained $64.663 \%$ percent of the total variance of the Internal business perspective.

\section{Customer satisfaction perspective}

From factor analysis under varimax rotation, two factors have been extracted under customer satisfaction perspective.

[Table 5]

\begin{tabular}{|c|c|c|c|}
\hline Factor & $\begin{array}{c}\text { Factor Interpretation } \\
\text { (\% variance } \\
\text { explained }\end{array}$ & Loading & $\begin{array}{l}\text { Variables included in the } \\
\text { factor }\end{array}$ \\
\hline \multirow[t]{4}{*}{$F_{1}$} & \multirow{4}{*}{$\begin{array}{l}\text { Customer oriented } \\
\text { return policy } \\
(38.599 \%)\end{array}$} & 0.767 & $\begin{array}{l}\text { Satisfactory product return } \\
\text { policy }\end{array}$ \\
\hline & & 0.730 & Customer retention \\
\hline & & 0.697 & $\begin{array}{l}\text { Increasing of new } \\
\text { customer }\end{array}$ \\
\hline & & 0.568 & Customer Survey. \\
\hline \multirow[t]{2}{*}{$F_{2}$} & \multirow[t]{2}{*}{$\begin{array}{l}\text { Customer survey } \\
\text { (25.110\%) }\end{array}$} & 0.901 & $\begin{array}{l}\text { Improved product and } \\
\text { service from improved } \\
\text { buisness process }\end{array}$ \\
\hline & & 0.498 & Customer Survey. \\
\hline
\end{tabular}

In all, the two factors explained $\quad 63.709 \%$ percent of the total variance of the customer satisfaction perspective Financial perspective

From factor analysis under varimax rotation, two factors have been extracted under financial perspective. [Table 6] 


\begin{tabular}{|c|c|c|c|}
\hline Factor & $\begin{array}{c}\text { Factor Interpretation } \\
\text { (\% variance } \\
\text { explained }\end{array}$ & Loading & $\begin{array}{c}\text { Variables included in the } \\
\text { factor }\end{array}$ \\
\hline \multirow{2}{*}{$\boldsymbol{F}_{\boldsymbol{1}}$} & $\begin{array}{c}\text { ROA } \\
(30.785 \%)\end{array}$ & 0.817 & Perecentage of ROA \\
\cline { 3 - 4 } & Net Income & 0.793 & Increased revenue \\
\hline $\boldsymbol{F}_{\mathbf{2}}$ & \multirow{2}{*}{$(29.531 \%)$} & 0.734 & Net Profit Percentage \\
\cline { 3 - 4 } & & & \\
\hline
\end{tabular}

In all, the two factors explained $60.315 \%$ percent of the total variance of the financial perspective.

Revised model of Balanced Scorecard:

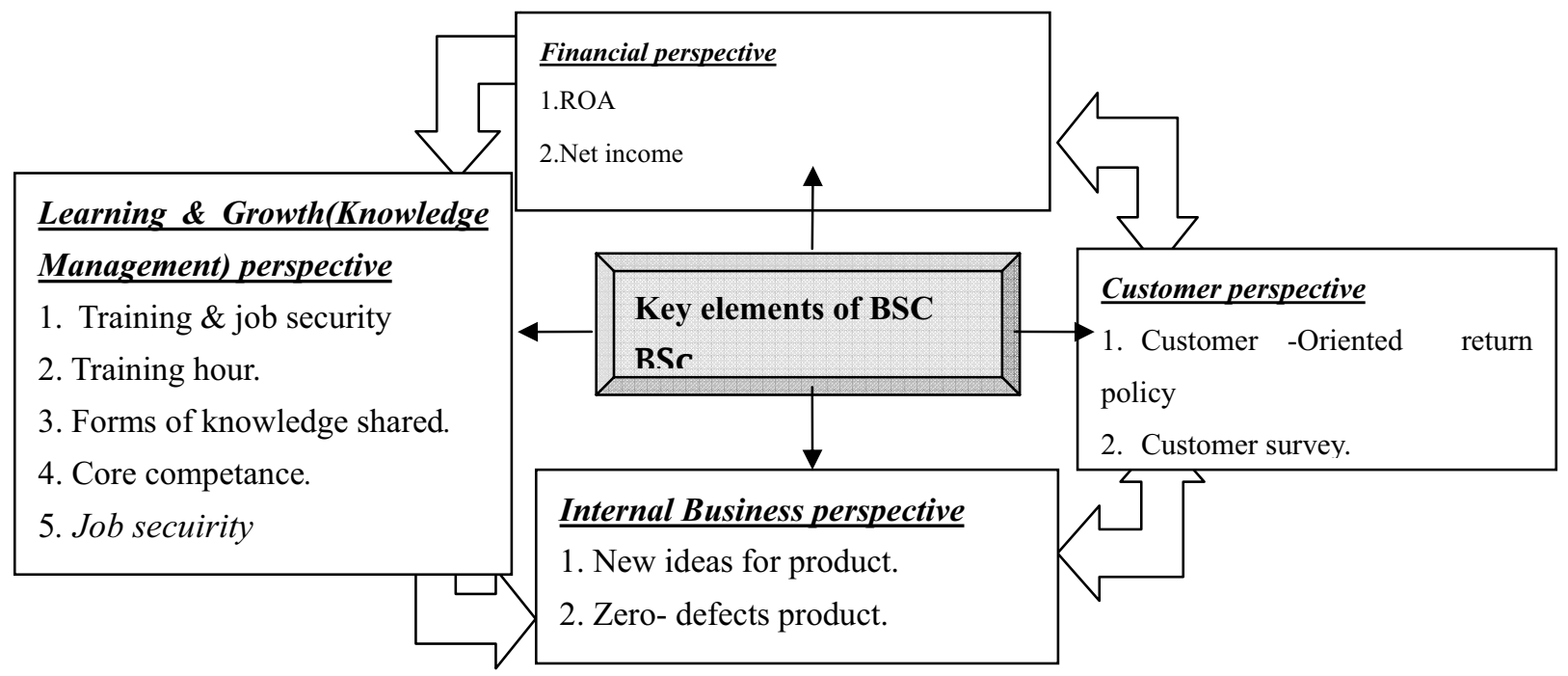

\section{Sources: Author's own compilation after using statistical tool.}

This revised model of Balanced Scorecard outlines the key factors of each of the four perspectives. This model has been developed based on the basic model of Balanced Scorecard (given earlier). Here, the elements of the basic model have been lessened down by use of factor analysis. The thirteen variables of Learning and growth perspective have been factored and the five key variables are identified after the analysis which are Training and job security, Training hour , Form of knowledge shared, Core competance, Job security. The revised two variables of Internal business process include new ideas for products, and Zero - defects product which have been drawn from four primary variables. The factor analysis has led to two major components of customer perspective; they are Customer oriented return policy and customer survey. Lastly, the four variables of financial perspective have been rotated through factor analysis and have resulted in two major variable which are Net income and ROA.

\section{Some comments in the light of findings}

Kaplan and Norton distinguish Financial, Internal, Customer, and Learning and Growth perspectives on organizational processes essential to an overall strategy. Looking at the original Kaplan and Norton implementation, Knowledge Management clearly fits within, if it does not define, the Learning and Growth aspect of their framework. If this is true, Knowledge Management outputs will impact on other processes. This is one reason why the significance in measuring knowledge management benefits or costs to other processes in organizations is an important area for extending the present Kaplan and Norton work (Firestone and Joesph, 1998).

In order to establish a BSC in a profit-oriented organization the first step is to devise a strategic blueprint for the organization for which the mission and activities of the organization should be strategically confederated. The strategic map should initiate with the aspect of learning and growth. From the detailed discussion of knowledge management (made at the inception of the paper), and from the empirical findings it can be summarized that it is a process which 
involves transforming the raw data (collected from both internal and external sources) into information and then again transfiguring this information into knowledge by use of human intuition and experience. To transform the information into knowledge, other than human insight and maturity, organizational support and capability (like policy and strategy inclination, manpower maturation \& human empowerment capability, technological \& information capability) are also needed. There should be a knowledge culture that will ensure creation and exchange of knowledge. This ultimate knowledge management will lead to a proper learning and growth of an organization on the ground that through knowledge, employees will acquire the skills and formulate and implement new options timely, accurately and efficiently. Thus, they will be competent to reconstruct the business process when needed according to the contemporary need of the market. This modernistic organized set up of the internal business process will satisfy the customers at a greater extent as new options and conveniences will be serviceable to the customers. This customer satisfaction will lead to a superior financial accomplishment with an increased sale leading to an augmented contribution margin and thus a heightening profit. (Figure 4)

\section{Insert Fugure 4 here}

\section{Conclusion and Recommendations and Limitation of the study.}

The paper attempts to connect Learning and Growth under knowledge management approach with BSC in Multinational organization of Bangladesh and to establish the fact that the success of knowledge management can be measured by Balanced Scorecard. The findings address that management experts of MNC have the same opinion that learning and growth is the key to strategic success, the foundation for the future. Empirical data from our survey results document that learning and growing organization is one in which knowledge management activities are deployed and expanded with a view to leverage the creativity of all the people in the organization The result also evidenced that BSC, as a strategic performance measurement tool helps in strategic management by linking some strategically significant, relevant and interrelated measures or indicators with organizational emphasis on knowledge and learning initiatives . In Figure 4, it has been revealed that how a proper and effective knowledge management process leads to cause and effect relationship of a BSC and produce the financial success of the organization. Thus it is inferred that whether appropriate knowledge management is done in the organization or not can be revealed through the indicators of BSC. Based on our findings following recommendations are drawn.

(1) The firm under study necessitates concentrating not only to rise in Net Income from the previous year but also rise in some other financial measures.

(2) Employees are to be given much flexibility to suggest in any types of problem solving provided they are knowledgeable in their own area.

(3) Continuous efforts are to be taken to upgrade customer relationship management through which organizational growth level will be exposed to the stakeholders group.

(4) Organization should be alert and should take required measure such as creating a healthy atmosphere for working, building solid place for showing the level of individual creativity, performance based bonus system and other promotional systems to stop employees' turnover which are indispensable for organization's smooth functioning.

(5) Regular in house and out door trainings and development programs has to be arranged to ensure the real knowledge flow and to update knowledge throughout the every segment of the organization.

(6) Users- friendly Information and communication system are to be used in order to amplify knowledge in every segment of the organization.

(7) Proper care must be taken to update Management Information System (MIS) which is believed as a solid centre for knowledge gathering, knowledge sharing, and knowledge exchange.

(8) Friendly learning and growth environment are to be formed where employees' will learn with no panic and not in a demoralized manner.

(9) For picking up the level of customer satisfaction regular customer survey must be conducted so that their perception about the product, their complaint can be heard and some suggestion can be sought which would ultimately be incorporated in complying companies' policy "customer care".

(10) Active program can necessarily be on track by the organization for continuous development of new idea derived from knowledge and growth which can easily be used for new product introduction, improving process, and services.

We believe that our findings are important for several reasons. The first reason is that we used the BSC framework as a general structure model with a link to knowledge management to establish the linkage of knowledge management parameters with financial performance. Our conclusion supports the lead- lag relationship evidenced from our empirical study. Thus if a company actually starts learning and growth initiative through knowledge management approach, if the company actually applies a BSC model successfully, more systematically monitor it, assess its contribution to 
performance and apply those measures properly, it will better suit with its profile. The second reason is that the firm under the study is a multinational organization and if an ultimate financial success of the organization is a result of the interrelated perspectives initiated with a good knowledge management practice and then leading to other perspectives of the BSC, it can be said that proper knowledge management practice is made when the indicators of BSC show satisfactory results. Thirdly ,managers can track measures as they work toward their objectives, and measurement metrics aid in showing how to build internal capacity, such as human capital, knowledge, and a knowledge culture. Besides a metrics frame work keeps measures from being ad hoc, providing a reference point for Knowledge management measurement after its implementation.

Nonetheless, the study itself is not free from certain shortcomings. The findings of the study must be interpreted with cautions as we applied knowledge management practices with linkage to BSC model only to one MNC. So generalization of results mentioned in the paper in other situation such as service concern or local manufacturing industries must be done carefully. Future research agenda can be set up to see the impact of knowledge management on those industries. A second limitation of this study is small sample size. Last of all, another lack of the current study is that the survey methodology basically measures belief rather than actions.

\section{References}

Aidemark, L.G. (2001). The Meaning of Balanced Scorecards in the Health Care Organization. Financial Accountability \& Management, Vol. 17 (1), February, 23- 40.

Akhter, S. H. (2003). Strategic Planning, Hyper Competition and Knowledge Management. Business Horizons, (January- February). 19-24.

Atkinson, A. A., Banker, R. D., Kaplan, R. S. and Young, S. M. (1997). Management Accounting, NJ, Prentice-Hall.

Atkinson, A.A. Balakrisliman, R., Booth, P., Cote, J.M., Groot, T., Malmi, T., Roberts, H., Uliana, E, and Wu, A. (1997). New Dimensions in Management Accounting Research, Journal of management Accounting Research, Vol.9, 80-108.

Awad, E. M. and Gliaziri, H. M. (2004). Knowledge Management, Pearson Education Singapore Pvt. Ltd, (Indian Branch), India.

Bagozzi R.P. (1994). Measurement of Marketing Research: Basic Principles of Questionnaire Design in R.P. Bagozzi (Ed.), Principles of Marketing Research, Oxford: Blackwell.

Boisot, M. (1998). Knowledge Assets, Oxford, ISBN 0-19-829086-1.

Berdlow, L. and Lane. H. W. (2003). International Joint Ventures: Creating Value through Successful Knowledge Management. Journal of World Business, Vol. 38, 15-30.

BMLConsulting and Griffith University School of Management. (2002). Knowledge Management Research Report ,2002 - Queensland.

Chow, C. W., Haddad, K. M., and Williamson, J. E. (1997). Applying Balanced Scorecard to Small companies, Management Accounting, Vol 79 (2), 21-22.

Civi.Emin. (2004). Knowledge Management as a Competitive Asset: a Review of originally published in the Journal of Marketing Intelligence \& Planning, Vol. 18 (4), Michigan, USA.

Drucker, Peter F. (1995). Managing in a Time of Great Change. New York: Truman Talley Books/Dutton.

David, F. R. (1999). Strategic Management: Concepts and Cases, 7th Edition, Prentice Hall International, Inc., New Jersey.

Davenport, T. and Prusak, L. (1997). Working Knowledge, Harvard 1998, ISBN 0-87584-655-6.

Davis, M. (2002). Knowledge Management - Re-valuing the Business, found in Knowledge point Ply LTD's official web site.

Desouza, K. C. (2003). Knowledge Management Barriers: Why the Technology Imperatives Seldom Works, Business Horizons, (January-February), 25-29.

Drucker, P. F. (1992). Be Data Literate- Know what to Know, Wall Street Journal, (December). 22.

Firestone, Joesph. (1998). Knowledge Management Metrics Development: A Technical Approach, Executive Information Systems, Inc. White Paper No. 10, June. [Online] Available: http://www.dkms.com/KMMeasurement.html

Hoque, Z., Mia, L. and Alam, M. (1997). Competition, New Manufacturing practices, Changes in MAS and Managerial choice of the "Balanced Scorecard" approach to performance measures: An empirical investigation, Paper presented at the European Accounting Association Annual Congress in Greece. 
Garrison H. Ray, Noreen W. Eric. (2000). Management Accounting, 9th edition, Mc. Graw- Hills, New York, NY.

Hoque, Z. and W. James. (2000). Linking Balanced Scorecard measures to size and market factors: Impact on organizational performance. Journal of Management Accounting Research, Vol. 12, 1 -17.

Hoque, Z. (2003). Strategic Management Accounting: Concepts, Processes and Issues, 2nd Edition, Spiro Press, USA.

Ishtiaque.A.N.A, Khan. Md. H.U.Z,. Akter. S, Fatema K Z. (2007). Perception Analysis of Balanced Scorecard -An Application over a Multinational Corporation of Bangladesh. Dhaka University Journal of Business Studies, Vol. 28 (2), pp.235-270, ISSN -1682-2498.

Jabnoun N, Chaker M. (2003). Comparing the Quality of Private and Public Hospitals, Managing service quality Vol. 13(4), 290-299.

Kaplan, R. S. (1992). Measuring Manufacturing Performance: A new Challenge for Management Accounting Research, Accounting Review, Vol. 28(4), 686-705.

Kaplan, R.S. and Norton, D.P. (1996). The Balanced Scorecard: Translating Strategy, into Action. Harvard Business School Press, Boston.

Kaplan. R.S. and Norton, D.P. (1996). Linking Balanced Scorecard to Strategy, California. Management Review, Fall, 59.

Kaplan, R.S and Atkinson, A. A. (1998). Advanced Management Accounting, 3rd edition, Pearson Education Asia, Singapore.

Kald, M. and Nilsson, F. (2000). Performance Measurement at Nordic Companies. European Management Journal, Vol. 1, 113-127.

Kaiser, H. (1974). An index of factorial simplicity, Psychometrika. Vol. 39, pp. 31-36.

Kabir A. A.K.M. (2005) .Balanced Scorecard (BSC) - A Tool for the Management. The Bangladesh Accounting. March-April.

Letza, S. R. (1996). The design and implementation of Balanced Business Scorecard: An Analysis of Three Companies in Practice, Business Process Reengineering \& Management Journal, Vol. 2 (3), 54-76.

Malmi, T. (2001). Balanced Scorecard in Finnish Companies: a Research Note. Management Accounting Research, Vol. 12 (2), 207-220.

Myers, P. S. (1996). Knowledge Management and Organizational Design: An Introduction. In Myers, P. S. (ed.), Knowledge Management and Organizational Design, Butterworth-Heinernann, Boston, 1-6.

Malhotra, K, Naresh. (2004).Marketing Research ,4 ${ }^{\text {th }}$ edition, Pearson Education, India.

Nunally, C.J. (1978). Psychometric Theory, McGraw- Hill, New York, NY.

Ogundipe, E. (2003). The Balanced Scorecard- A Simple Perspective, Management Accounting Research, Vol. 12, 155-157

Otley.D. (1994). Management Control in Contemporary Organizations: Towards a Wider Framework, Management Accounting Research, Vol.5, 289-299.

Pallant, J. (2001) . SPSS Survival Manual, 1st ed. Allen \& Unwin, Australia.

Silk, S. (1998). Automating the Balanced Scorecard, Management Accounting, May, 38-44.

Rampersad, H.K. (2001). Total Quality Management; An executive guide to Continuous Improvement, Springer-Verlag, New York, (February)

Rampersad, H.K. (2002). Total Performance Scorecard; een speurtocht naar zelfkennis en competentieontwikkeling van lerende organisaties, Scriptum Management, Schiedam, (September).

Stephens, D. (2000). Knowledge Management in the APS: A Stock take and a Prospectus. [Online] Available: www.intellcap.com.au

Tiwana, A. (2000). The Knowledge Management Toolkit, Prentice Hall, NJ.

Zander, U. and Kogut, B. (1992). Knowledge of a firm: Combinative Capabilities and the Replication of Technology. Organization Science, 3(3), 383-397.

Zikmund G. William. (2003). Business Research Methods, $7^{\text {th }}$ edition, 389. 
Table 1. Method 2 (covariance matrix) will be used for this analysis $* * * * * *$

RELIA B ILITY ANALYSIS - SCALE (ALPHA)

\begin{tabular}{|c|c|c|c|c|}
\hline & & Mean & Std Dev & Cases \\
\hline 1. & SUGGES_ & 3.2931 & 1.4019 & 58.0 \\
\hline 2. & TRAING & 2.7759 & 1.0267 & 58.0 \\
\hline 3. & TURNOVER & 2.6724 & 1.0494 & 58.0 \\
\hline 4. & HOURS & 2.4138 & 0.7501 & 58.0 \\
\hline 5. & SECURITY & 2.9138 & 1.1283 & 58.0 \\
\hline 6. & COMPETEN & 3.8276 & 0.9936 & 58.0 \\
\hline 7. & INFORMAL & 3.8621 & 0.6609 & 58.0 \\
\hline 8. & INTERNET & 3.7069 & 0.9913 & 58.0 \\
\hline 9. & MISTAKE & 3.0517 & 0.9629 & 58.0 \\
\hline 10. & NECE & 3.3966 & 1.1689 & 58.0 \\
\hline 11. & COLLECTI & 2.7241 & 1.1207 & 58.0 \\
\hline 12. & USERS & 2.8793 & 1.0609 & 58.0 \\
\hline 13. & MIS & 3.1897 & 1.1766 & 58.0 \\
\hline 14. & PRODUCT & 3.2759 & 1.1207 & 58.0 \\
\hline 15. & ACTIVE & 3.1034 & 1.0872 & 58.0 \\
\hline 16. & PROPER & 3.5862 & 0.9918 & 58.0 \\
\hline 17. & DEFECT & 3.6724 & 1.0155 & 58.0 \\
\hline 18. & PROCESS & 3.4483 & 1.2019 & 58.0 \\
\hline 19. & C.SATIS & 3.3103 & 1.4413 & 58.0 \\
\hline 20. & P.RTN & 3.6724 & 1.0824 & 58.0 \\
\hline 21. & C.RETENT & 3.9138 & 0.8010 & 58.0 \\
\hline 22. & NEW.CU & 3.7069 & 1.1240 & 58.0 \\
\hline 23. & REVENUES & 3.8621 & 1.0336 & 58.0 \\
\hline 24. & GM & 3.5862 & 1.1703 & 58.0 \\
\hline 25. & $\mathrm{NP}$ & 4.2069 & 0.8738 & 58.0 \\
\hline 26. & ROA & 4.0690 & 0.9887 & 58.0 \\
\hline
\end{tabular}


$\mathrm{N}$ of Cases $=58.0$

No of

Statistics for

Mean Variance Std Dev Variables

Scale

$88.1207 \quad 71.7922$

8.4730

26

Item Means

Mean Minimum Maximum

Range Max/Min

RELIABILITY ANALYSIS - SCALE (A LPHA)

Reliability Coefficients 26 items

Alpha $=.6104 \quad$ Standardized item alpha $=.6132$

Table 2. One-Sample t Test of Learning and growth, Internal Business Process, Customer satisfaction and financial perspective

\begin{tabular}{|c|c|c|c|c|c|c|}
\hline \multirow{2}{*}{\begin{tabular}{|lll}
$\begin{array}{l}\text { Learning and growth } \\
\text { perspective }\end{array}$ & \\
\end{tabular}} & \multicolumn{6}{|c|}{$\begin{array}{ll}\text { Test } & \text { Value } \\
=03 & \end{array}$} \\
\hline & & df & $\begin{array}{l}\text { Sig. } \\
(2 \text {-tailed })\end{array}$ & \begin{tabular}{|l} 
Mean \\
Difference
\end{tabular} & $\begin{array}{l}\text { 95\% Confidence } \\
\text { Interval of the } \\
\text { Difference }\end{array}$ & \\
\hline & & & & & Lower & Upper \\
\hline $\begin{array}{l}\text { Suggestion from employees } \\
\text { are encouraged by the top } \\
\text { management }\end{array}$ & 1.773 & 59 & .081 & .32 & $-4.08 \mathrm{E}-02$ & .67 \\
\hline $\begin{array}{|lcr|}\text { Organizations } & \text { conduct } & \mathrm{s} \\
\text { frequent } & \text { training } & \text { and } \\
\text { development } & \text { program } & \text { for } \\
\text { employees } & & \\
\end{array}$ & -1.516 & 59 & .135 & -.20 & -.46 & $6.40 \mathrm{E}-02$ \\
\hline Employee turnover is low & -2.337 & 59 & .023 & -.32 & -.59 & $-4.56 \mathrm{E}-02$ \\
\hline $\begin{array}{l}\text { Number of hours spent for- } \\
\text { training per employee is high }\end{array}$ & -5.543 & 59 & .000 & -.55 & -.75 & -.35 \\
\hline Job security is ensured & -.462 & 59 & .646 & $-6.67 \mathrm{E}-02$ & -.36 & .22 \\
\hline $\begin{array}{l}\text { Knowledge and learning } \\
\text { competences are part of every } \\
\text { employees competence profile }\end{array}$ & 6.606 & 59 & .000 & .83 & .58 & 1.09 \\
\hline 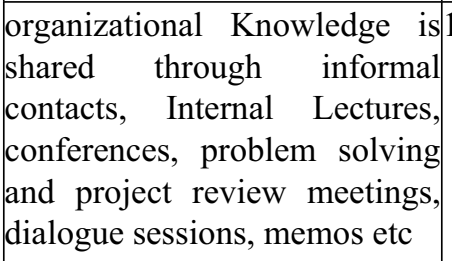 & 10.271 & 59 & .000 & .88 & .71 & 1.06 \\
\hline $\begin{array}{l}\text { Knowledge sharing is } \\
\text { facilitated through internet, } \\
\text { intranet, library, comfortable } \\
\text { meeting rooms, auditorium } \\
\text { computerized archive and } \\
\text { documentation system etc }\end{array}$ & 5.742 & 59 & .000 & .73 & .48 & .99 \\
\hline $\begin{array}{l}\text { Making mistakes are allowed; } \\
\text { Failures are tolerated and not } \\
\text { penalized. People learn from } \\
\text { each other's mistakes, and }\end{array}$ & 409 & 59 & .684 & $5.00 \mathrm{E}-02$ & -.19 & .29 \\
\hline
\end{tabular}




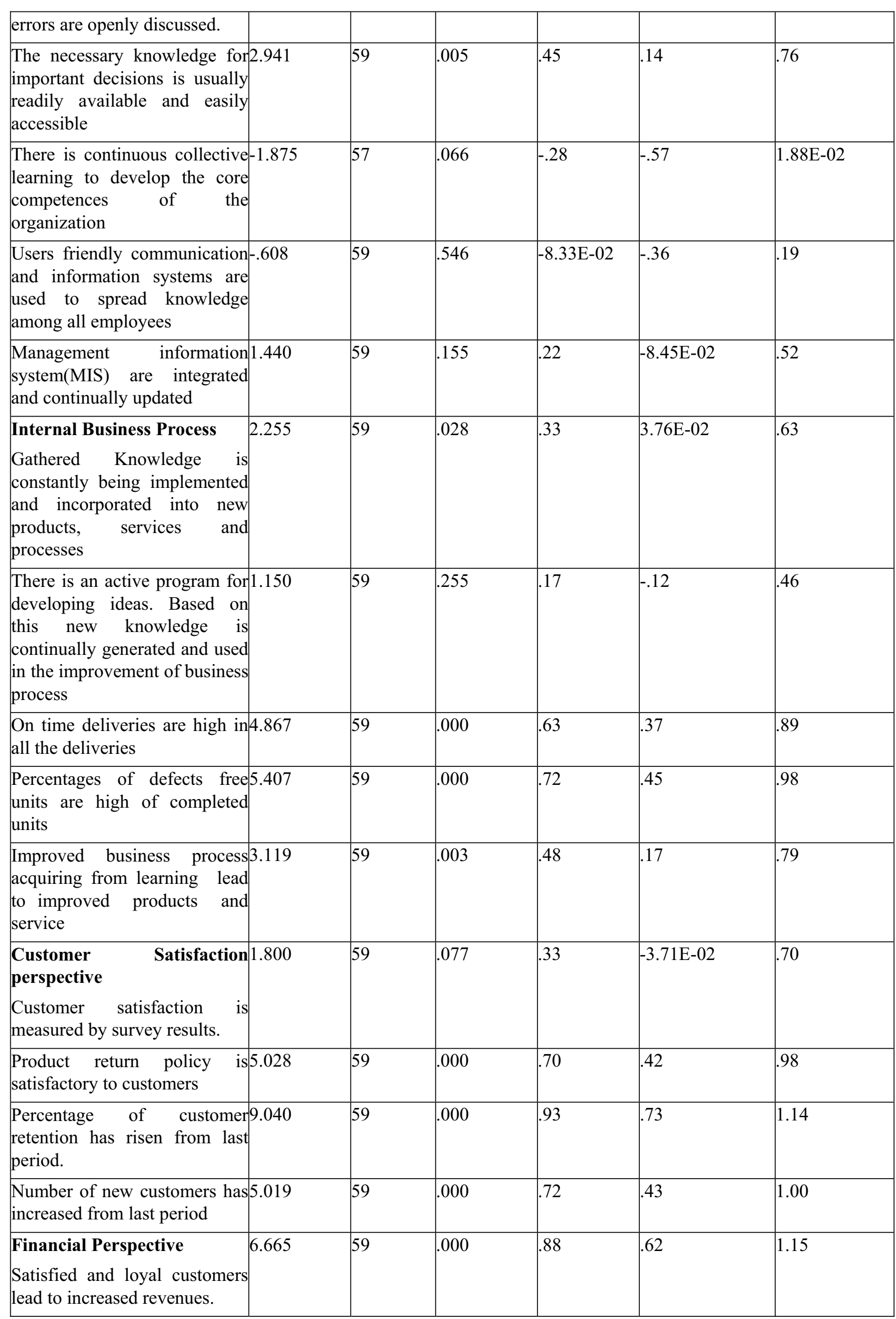




\begin{tabular}{|l|l|l|l|l|l|l|}
\hline $\begin{array}{l}\text { Gross margin percentage has } 4.097 \\
\text { increased from the last period. }\end{array}$ & 59 & .000 & .62 & .32 & .92 \\
\hline $\begin{array}{l}\text { Net Income percentage has } 10.813 \\
\text { increased from the last period. }\end{array}$ & 59 & .000 & 1.20 & .98 & 1.42 \\
\hline $\begin{array}{l}\text { ROA percentage has increased } 8.367 \\
\text { from the last period. }\end{array}$ & 58 & .000 & 1.07 & .81 & 1.32 \\
\hline
\end{tabular}

Table 3. Factor Analysis for Knowledge Management

Total Variance Explained under Learning and Growth (Knowledge Management)

\begin{tabular}{|c|c|c|c|c|c|c|c|c|c|}
\hline \multirow[b]{2}{*}{ Component } & \multicolumn{3}{|c|}{$\begin{array}{c}\text { Initial } \\
\text { Eigenval } \\
\text { ues }\end{array}$} & \multicolumn{3}{|c|}{$\begin{array}{c}\text { Extraction } \\
\text { Sums of } \\
\text { Squared } \\
\text { Loadings }\end{array}$} & \multicolumn{3}{|c|}{$\begin{array}{l}\text { Rotation } \\
\text { Sums of } \\
\text { Squared } \\
\text { Loadings }\end{array}$} \\
\hline & Total & $\begin{array}{c}\% \% \text { of } \\
\text { Variance }\end{array}$ & Cumulative $\%$ & Total & $\begin{array}{c}\text { \% of } \\
\text { Variance }\end{array}$ & $\begin{array}{c}\text { Cumulative } \\
\%\end{array}$ & Total & $\begin{array}{c}\text { \% of } \\
\text { Variance }\end{array}$ & $\begin{array}{c}\text { Cumulative } \\
\%\end{array}$ \\
\hline 1 & 3.090 & 23.771 & 23.771 & 3.090 & 23.771 & 23.771 & 2.241 & 17.237 & 17.237 \\
\hline 3 & 1.791 & 13.776 & 53.257 & 1.791 & 13.776 & 53.257 & 2.051 & 15.776 & 49.159 \\
\hline 4 & 1.635 & 12.575 & 65.832 & 1.635 & 12.575 & 65.832 & 1.832 & 14.089 & 63.248 \\
\hline 5 & 1.240 & 9.535 & 75.367 & 1.240 & 9.535 & 75.367 & 1.428 & 10.982 & 74.230 \\
\hline 6 & 1.042 & 8.019 & 83.386 & 1.042 & 8.019 & 83.386 & 1.190 & 9.156 & 83.386 \\
\hline 9 & .391 & 3.011 & 96.343 & & & & & & \\
\hline 10 & .196 & 1.510 & 97.853 & & & & & & \\
\hline 11 & .152 & 1.168 & 99.021 & & & & & & \\
\hline 12 & .104 & .800 & 99.821 & & & & & & \\
\hline 13 & $2.322 \mathrm{E}-02$ & .179 & 100.000 & & & & & & \\
\hline
\end{tabular}

Extraction Method: Principal Component Analysis. 


\section{Rotated Component Matrix}

\begin{tabular}{|c|c|c|c|c|c|c|}
\hline & & & Component & & & \\
\hline & 1 & 2 & 3 & 4 & 5 & 6 \\
\hline $\begin{array}{l}\text { Suggestion from employees are. } \\
\text { encouraged by the top management }\end{array}$ & 123 & .166 & .288 & .848 & -.187 & .167 \\
\hline $\begin{array}{l}\text { Organizations conduct s frequent. } \\
\text { training and development program } \\
\text { for employees }\end{array}$ & .256 & 8.800E-02 & .896 & $-7.452 \mathrm{E}-02$ & .102 & .100 \\
\hline Employee turnover is low & $-8.631 \mathrm{E}-02$ & $2.253 \mathrm{E}-02$ & .903 & .284 & $2.394 \mathrm{E}-03$ & $-5.121 \mathrm{E}-02$ \\
\hline $\begin{array}{l}\text { Number of hours spent for training } \\
\text { per employee is high }\end{array}$ & $8.774 \mathrm{E}-02$ & .941 & .241 & .124 & $\begin{array}{l}-5.046 \mathrm{E}-0 \\
2\end{array}$ & $5.871 \mathrm{E}-03$ \\
\hline Job security is ensured & .280 & $-8.501 \mathrm{E}-02$ & .334 & -.296 & .758 & -.210 \\
\hline $\begin{array}{l}\text { Knowledge and learning } \\
\text { competences are part of every } \\
\text { employees competence profile }\end{array}$ & $8.115 \mathrm{E}-02$ & -.123 & $-3.349 \mathrm{E}-02$ & .903 & .122 & -.115 \\
\hline $\begin{array}{l}\text { organizational Knowledge is shared } \\
\text { through informal contacts, Internal } \\
\text { Lectures, conferences, problem } \\
\text { solving and project } \\
\text { meetings, dialogue rew } \\
\text { memos etc }\end{array}$ & 609 & .570 & .250 & .109 & .295 & $-8.511 \mathrm{E}-02$ \\
\hline $\begin{array}{l}\text { Knowledge sharing is facilitated } \\
\text { through internet, intranet, library, } \\
\text { comfortable meeting rooms, } \\
\text { auditorium computerized archive } \\
\text { and documentation system etc }\end{array}$ & 212 & .868 & -.194 & -.166 & $\begin{array}{l}-4.932 \mathrm{E}-0 \\
2\end{array}$ & -.140 \\
\hline $\begin{array}{l}\text { Making mistakes are allowed; } \\
\text { Failures are tolerated and not } \\
\text { penalized. People learn from each } \\
\text { other's mistakes, and errors are } \\
\text { openly discussed. }\end{array}$ & 842 & .129 & -.136 & $7.521 \mathrm{E}-03$ & .200 & .258 \\
\hline $\begin{array}{l}\text { The necessary knowledge for } \\
\text { important decisions is usually } \\
\text { readily available and easily } \\
\text { accessible }\end{array}$ & $-5.449 \mathrm{E}-02$ & -.133 & $5.021 \mathrm{E}-02$ & $1.558 \mathrm{E}-02$ & $3.445 \mathrm{E}-02$ & .926 \\
\hline $\begin{array}{l}\text { there is continuous collective } \\
\text { learning to develop the core } \\
\text { competences of the organization }\end{array}$ & -.235 & $2.165 \mathrm{E}-03$ & $-6.230 \mathrm{E}-02$ & .131 & .744 & .173 \\
\hline $\begin{array}{l}\text { Users friendly communication and } \\
\text { information systems are used to } \\
\text { spread knowledge among all } \\
\text { employees }\end{array}$ & -.694 & .155 & -.207 & $-3.354 \mathrm{E}-02$ & .260 & .137 \\
\hline $\begin{array}{l}\text { Management } \quad \text { information } \\
\text { system(MIS) are integrated and } \\
\text { continually updated }\end{array}$ & -629 & .133 & -.107 & -.223 & .199 & .303 \\
\hline
\end{tabular}

Extraction Method: Principal Component Analysis. $\quad$ Rotation Method: Varimax with Kaiser Normalization.

a Rotation converged in 17 iterations. 
Table 4. Factor Analysis for Internal Business Process

Total Variance Explained under Internal Business process

\begin{tabular}{|c|c|c|c|c|c|c|c|c|c|}
\hline & \multicolumn{3}{|c|}{$\begin{array}{c}\text { Initial } \\
\text { Eigen } \\
\text { values }\end{array}$} & \multicolumn{3}{c|}{$\begin{array}{c}\text { Extraction } \\
\text { Sums of } \\
\text { Squared } \\
\text { Loadings }\end{array}$} & \multicolumn{3}{c|}{$\begin{array}{c}\text { Rotation } \\
\text { Sums of } \\
\text { Squared } \\
\text { Loadings }\end{array}$} \\
\hline $\begin{array}{c}\text { Compone } \\
\text { nt }\end{array}$ & Total & $\begin{array}{c}\text { \% of } \\
\text { Variance }\end{array}$ & $\begin{array}{c}\text { Cumulativ } \\
\text { e \% }\end{array}$ & Total & $\begin{array}{c}\text { \% of } \\
\text { Variance }\end{array}$ & $\begin{array}{c}\text { Cumulative } \\
\text { \% }\end{array}$ & Total & $\begin{array}{c}\text { \% of } \\
\text { Variance }\end{array}$ & $\begin{array}{c}\text { Cumulative } \\
\text { \% }\end{array}$ \\
\hline 1 & 1.554 & 38.841 & 38.841 & 1.554 & 38.841 & 38.841 & 1.475 & 36.886 & 36.886 \\
\hline 2 & 1.033 & 25.822 & 64.663 & 1.033 & 25.822 & 64.663 & 1.111 & 27.777 & 64.663 \\
\hline 3 & .911 & 22.779 & 87.442 & & & & & & \\
\hline 4 & .502 & 12.558 & 100.000 & & & & & & \\
\hline
\end{tabular}

Extraction Method: Principal Component Analysis.

\section{Rotated Component Matrix}

\begin{tabular}{|l|l|l|}
\hline & \multicolumn{2}{l|}{ Component } \\
\cline { 2 - 3 } & 1 & 2 \\
\hline $\begin{array}{l}\text { Gathered Knowledge is constantly being implemented } \\
\text { and incorporated into new products, services and } \\
\text { processes }\end{array}$ & -.112 \\
\hline $\begin{array}{l}\text { There is an active program for developing ideas. Based } \\
\text { on this new knowledge is continually generated and } \\
\text { used in the improvement of business process }\end{array}$ & .206 \\
\hline $\begin{array}{l}\text { Percentages of defects free units are high of completed } \\
\text { units }\end{array}$ & .159 & .820 \\
\hline On time deliveries are high in all the deliveries & .376 & .620 \\
\hline
\end{tabular}

Extraction Method: Principal Component Analysis.

Rotation Method: Varimax with Kaiser Normalization.

a Rotation converged in 3 iterations.

Table 5. Factor Analysis for customer satisfaction Perspective

Total Variance Explained

\begin{tabular}{|c|c|c|c|c|c|c|c|c|c|}
\hline & \multicolumn{3}{|c|}{$\begin{array}{c}\text { Initial } \\
\text { Eigenvalues }\end{array}$} & \multicolumn{3}{c|}{$\begin{array}{c}\text { Extraction } \\
\text { Sums of } \\
\text { Squared } \\
\text { Loadings }\end{array}$} & \multicolumn{3}{c|}{$\begin{array}{c}\text { Rotation } \\
\text { Sums of } \\
\text { Squared } \\
\text { Loadings }\end{array}$} \\
\hline Component & Total & $\begin{array}{c}\text { \% of } \\
\text { Variance }\end{array}$ & $\begin{array}{c}\text { Cumulative } \\
\%\end{array}$ & Total & $\begin{array}{c}\text { \% of } \\
\text { Variance }\end{array}$ & $\begin{array}{c}\text { Cumulative } \\
\%\end{array}$ & Total & $\begin{array}{c}\text { \% of } \\
\text { Variance }\end{array}$ & $\begin{array}{c}\text { Cumulative } \\
\%\end{array}$ \\
\hline 1 & 2.054 & 41.090 & 41.090 & 2.054 & 41.090 & 41.090 & 1.930 & 38.599 & 38.599 \\
\hline 2 & 1.131 & 22.619 & 63.709 & 1.131 & 22.619 & 63.709 & 1.255 & 25.110 & 63.709 \\
\hline 3 & .681 & 13.612 & 77.321 & & & & & & \\
\hline 4 & .598 & 11.964 & 89.285 & & & & & & \\
\hline 5 & .536 & 10.715 & 100.000 & & & & & & \\
\hline
\end{tabular}

Extraction Method: Principal Component Analysis. 


\section{Rotated Component Matrix}

\begin{tabular}{|l|l|l|}
\hline \multicolumn{2}{|l|}{} & \multicolumn{2}{l|}{ Component } \\
\cline { 2 - 4 } & 1 & 2 \\
\hline $\begin{array}{l}\text { Improved business process acquiring from } \\
\text { learning lead to improved products } \\
\text { and service }\end{array}$ & & $.081 \mathrm{E}-03$ \\
\hline $\begin{array}{l}\text { Customer satisfaction is measured by } \\
\text { survey results. }\end{array}$ & .568 & .491 \\
\hline $\begin{array}{l}\text { Product return policy is satisfactory to } \\
\text { customers }\end{array}$ & -767 & -.324 \\
\hline $\begin{array}{l}\text { Percentage of customer retention has risen } \\
\text { from last period. }\end{array}$ & 730 & $9.846 \mathrm{E}-02$ \\
\hline $\begin{array}{l}\text { Number of new customers has increased } \\
\text { from last period }\end{array}$ & & \\
\hline
\end{tabular}

Extraction Method: Principal Component Analysis.

Rotation Method: Varimax with Kaiser Normalization.

a Rotation converged in 3 iterations.

Table 6. Factor Analysis for financial perspective

Total Variance Explained under financial perspective.

\begin{tabular}{|c|c|c|c|c|c|c|c|c|c|}
\hline & \multicolumn{3}{|c|}{$\begin{array}{c}\text { Initial } \\
\text { Eigenval } \\
\text { ues }\end{array}$} & \multicolumn{3}{c|}{$\begin{array}{c}\text { Extractio } \\
\text { n Sums of } \\
\text { Squared } \\
\text { Loadings }\end{array}$} & \multicolumn{3}{c|}{$\begin{array}{c}\text { Rotation } \\
\text { Sums of } \\
\text { Squared } \\
\text { Loadings }\end{array}$} \\
\hline Component & Total & $\begin{array}{c}\text { \% of } \\
\text { Variance }\end{array}$ & $\begin{array}{c}\text { Cumulat } \\
\text { ive \% }\end{array}$ & Total & $\begin{array}{c}\text { \% of } \\
\text { Variance }\end{array}$ & $\begin{array}{c}\text { Cumulative } \\
\%\end{array}$ & Total & $\begin{array}{c}\text { \% of } \\
\text { Variance }\end{array}$ & $\begin{array}{c}\text { Cumulative } \\
\text { \% }\end{array}$ \\
\hline 1 & 1.249 & 31.223 & 31.223 & 1.249 & 31.223 & 31.223 & 1.231 & 30.785 & 30.785 \\
\hline 2 & 1.164 & 29.093 & 60.315 & 1.164 & 29.093 & 60.315 & 1.181 & 29.531 & 60.315 \\
\hline 3 & .938 & 23.441 & 83.756 & & & & & & \\
\hline 4 & .650 & 16.244 & 100.000 & & & & & & \\
\hline
\end{tabular}

Extraction Method: Principal Component Analysis.

\section{Rotated Component Matrix}

\begin{tabular}{|l|l|l|}
\hline \multirow{2}{*}{} & \multicolumn{2}{|l|}{ Component } \\
\cline { 2 - 3 } & 1 & 2 \\
\hline $\begin{array}{l}\text { Satisfied and loyal customers lead to. } \\
\text { increased revenues. }\end{array}$ & $-6.911 \mathrm{E}-02$ \\
\hline $\begin{array}{l}\text { Gross margin percentage has } \\
\text { increased from the last period. }\end{array}$ & & .146 \\
\hline $\begin{array}{l}\text { Net Income percentage has increased. } \\
\text { from the last period. }\end{array}$ & .734 \\
\hline $\begin{array}{l}\text { ROA percentage has increased from } \\
\text { the last period. }\end{array}$ & .817 & $3.935 \mathrm{E}-02$ \\
\hline
\end{tabular}

Extraction Method: Principal Component Analysis.

Rotation Method: Varimax with Kaiser Normalization.

a Rotation converged in 3 iterations. 


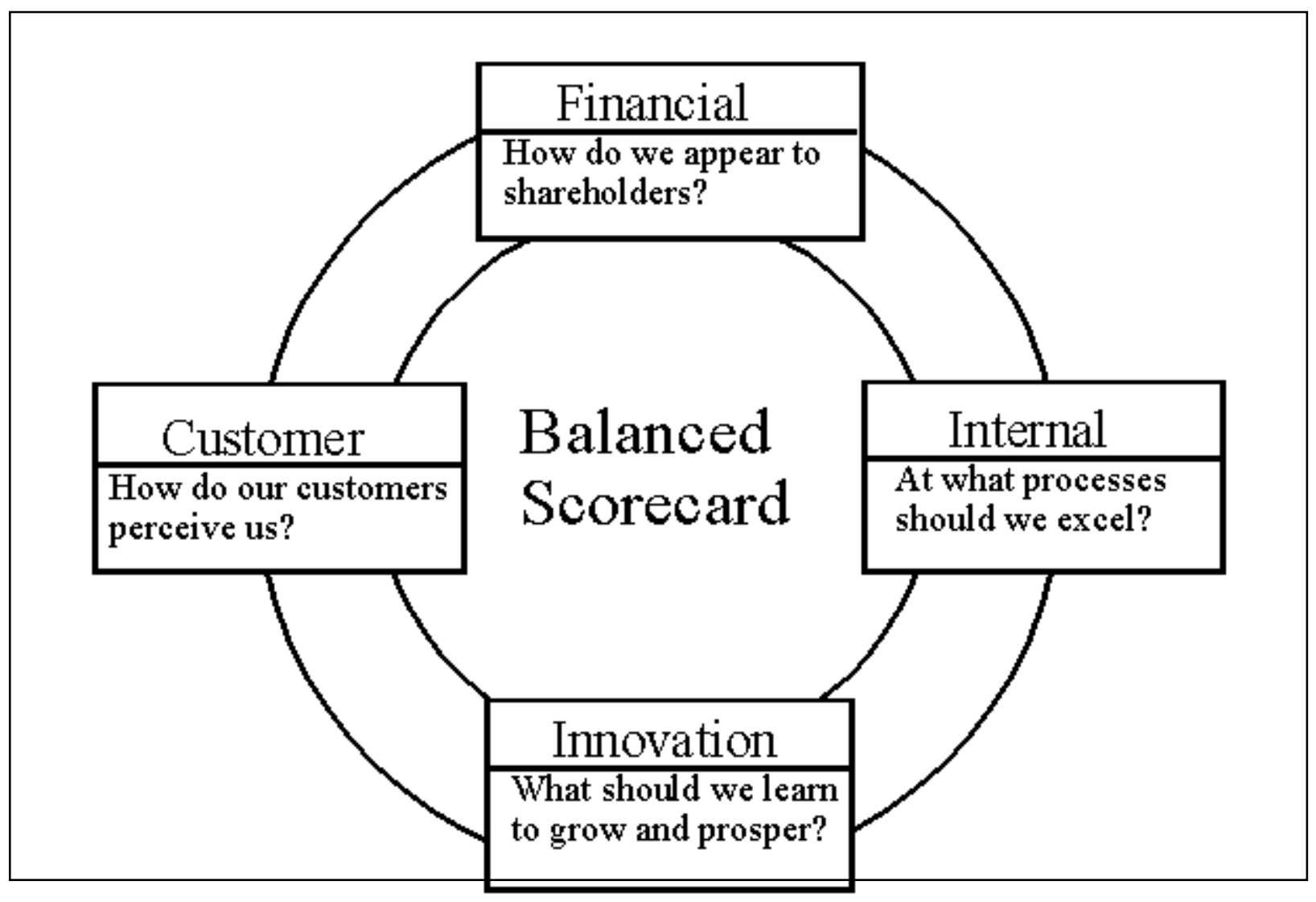

Figure 1. The Balance scorecard. Harvard Business School Press: 9

Sources: Kaplan and Norton (1996). 
Satisfied and loyal customers lead to increased revenue

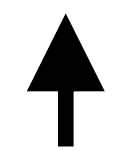

Improved business processes lead to

improved products and services for customers by saving time, quick delevery

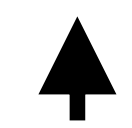

Skilled, creative employees question the status quo and work to improve business processes.

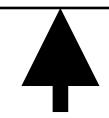

Learning and growth of employees

(Knowledge Management) is the

foundation for innovation and creativity

Figure 2. Cause and Effect Relationship

Source: Kaplan, R.S. and Norton. D.P. (1996). The Balanced Scorecard Translating Strategy into Action. Harvard Business School Press, Boston. 


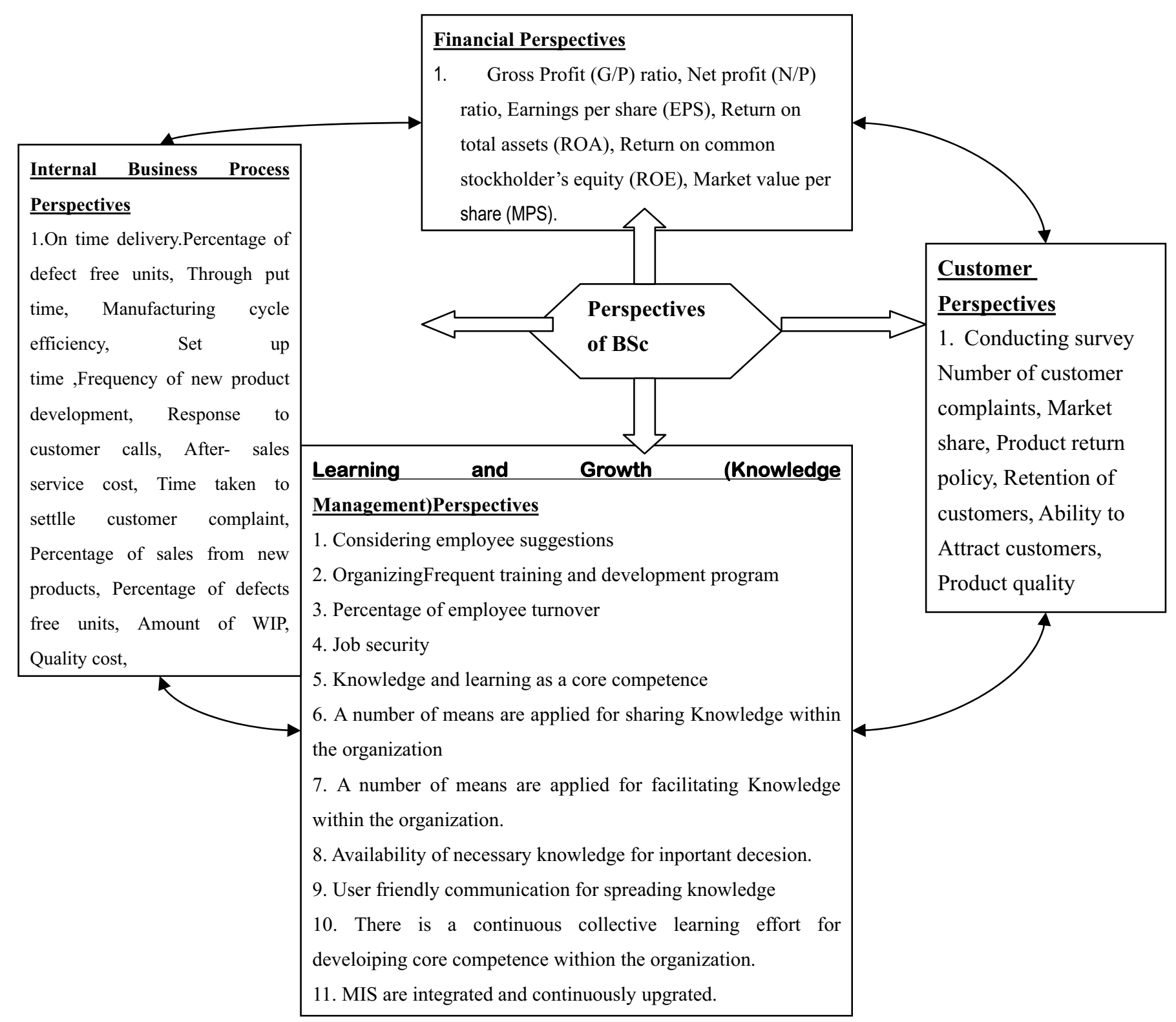

Figure 3. Model Development 


\section{Balanced}

Scorecard

Perspectives
Strategic

Management

activities
Measures of

Strategic Management activities

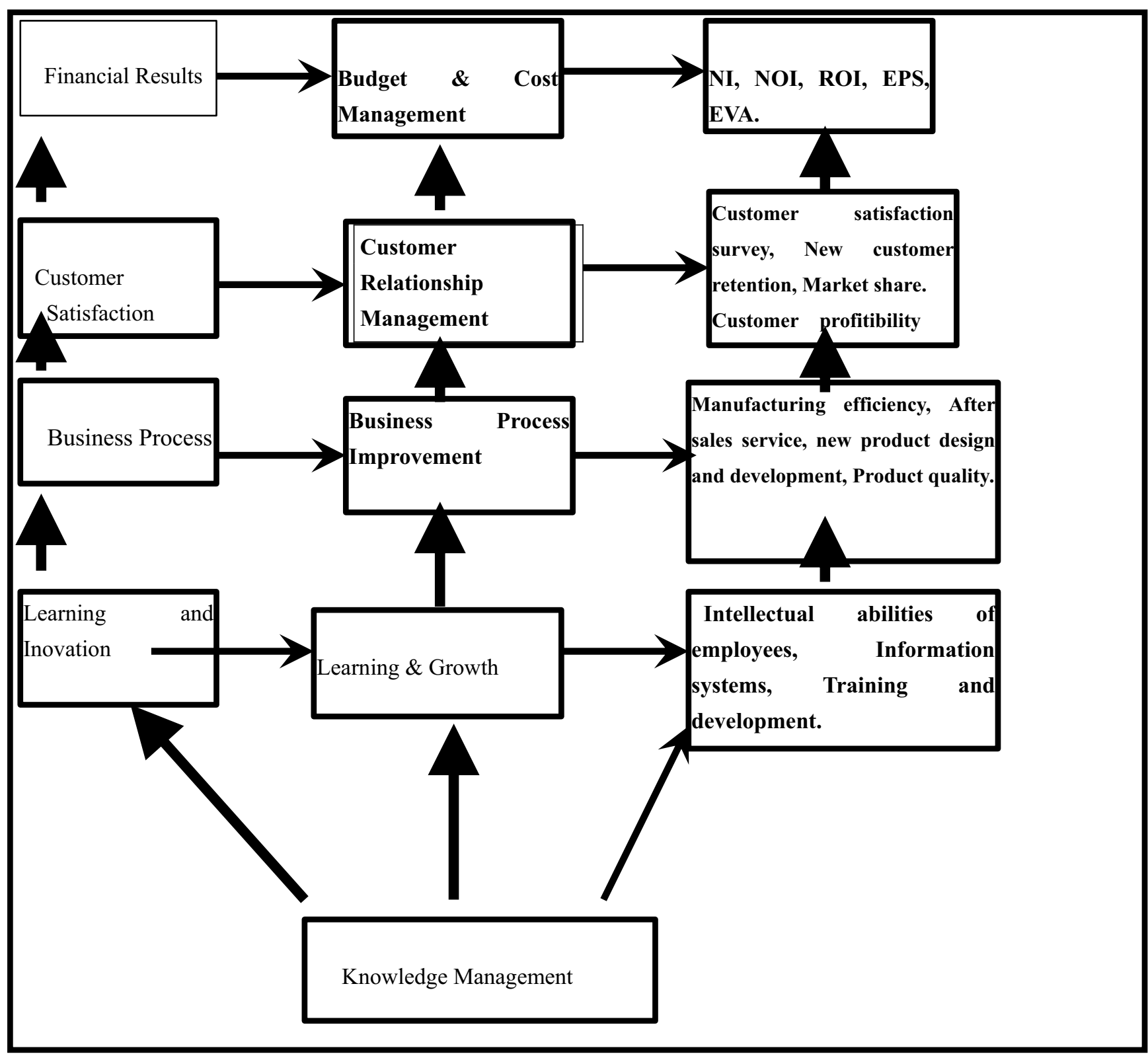

Figure 4. Linking between Knowledge Management and Organizational learning and growth activities through BSC. Sources: Garrison H. Ray, Noreen W. Eric. 2000. Management Accounting, Mc Graw- Hills .NY 